\title{
Rhabdomyosarcoma Orbita
}

\author{
Elfi Risalma Puteri ${ }^{1}$, Ardizal Rahman ${ }^{2}$
}

\begin{abstract}
Abstrak
Rhabdomyosarcoma (RMS) merupakan tumor ganas pada jaringan lunak yang sering mengenai anak-anak. Lokasi primernya $25-30 \%$ pada orbita. Tumor ini merupakan tumor yang agresif dengan kecenderung terjadi invasif lokal dan dapat terjadi rekurensi lokal, dengan metastasis secara hematogen dan limfatik. Dilaporkan kasus Rhabdomyosarcoma orbita pada anak laki-laki umur 12 tahun dengan progresivitas yang cepat , dengan hasil pemeriksaan patologi anatomi menunjukkan suatu embryonal rhabdomyosarcoma retroorbita serta penatalaksanaannya. Saat ini penatalaksanaan RMS orbita tidak hanya dengan penatalaksanaan bedah saja, dengan perkembangan radioterapi dan khemoterapi dapat meningkatkan survival rate penderita RMS. Selain itu dibutuhkan kolaborasi antara Konsultan Onkologi Mata dengan Bedah Saraf serta Konsultan Pediatrik Onkologi.
\end{abstract}

Kata kunci: rhabdomyosarcoma orbita, diagnosis rhabdomyosarcoma, penatalaksanaan rhabdomyosarcoma

\begin{abstract}
Rhabdomyosarcoma (RMS) is a malignant tumor of soft tissue that often affects children. The primary location is $25-30 \%$ on the orbit. The tumor was an aggressive tumor, which tend to be locally invasive and local recurrence can occur, with hematogenous and lymphatic metastases. Reported a case of orbital Rhabdomyosarcoma in 12-year-old boys with rapid progression, with the results of anatomical pathology examination showing a retroorbital embryonal rhabdomyosarcoma and its management. Management of Orbital RMS is not only with surgical management, Combination surgery with radiotherapy and chemotherapy can increase the survival rate of RMS patients. In addition, its important to manage with collaboration between Oncology Subdivision, Neurosurgery and Pediatric Oncology subdivision.
\end{abstract}

Keywords: orbital Rhabdomyosarcoma, diagnosis challenges, management rhabdomyosarcoma

Affiliasi penulis: 1. Dinas Kesehatan Kota Padang Panjang, 2. Bagian IImu Kesehatan Mata Fakultas Kedokteran Universitas Andalas Padang.

Korespondensi : elfirisalma@gmail.com Telp.081276163810

\section{PENDAHULUAN}

Rhabdomyosarcoma (RMS) merupakan tumor ganas pada jaringan lunak yang sering mengenai anak-anak, diperkirakan $5 \%$ dari semua tumor ganas pada anak dan $20 \%$ dari semua keganasan yang mengenai jaringan lunak. ${ }^{1}$ Lokasi primer dari RMS diantaranya kepala dan leher (45\%), di tubuh (40\%), ektremitas (15\%) dan kira-kira 25\%-30\% dari RMS pada kepala dan leher berasal dari orbita. ${ }^{1}$ Berdasarkan data epidemiologi, insiden rata-rata per tahun RMS okular adalah $0.13 / 100000$, di USA ditemukan 350 kasus baru RMS per tahun dimana 35 kasus atau 10\% diantaranya adalah RMS Orbita. $^{2}$ Insiden ini meningkat setiap tahunnya sekitar $1.16 \%$ per tahun dan dan survival rate RMS orbita diperkirakan $84.3 \%$. $^{3}$

RMS Orbita diduga berasal dari otot-otot lurik pada orbita dan struktur orbita, namun baru-baru ini diyakini bahwa RMS orbita tidak hanya berasal dari otot-otot ekstra okular tetapi berasal dari sel-sel yang tidak mengalami diferensiasi (undifferentiated) pada orbita. ${ }^{4}$ Tumor ini merupakan tumor yang agresif, dengan kecenderung terjadi invasif lokal dan dapat terjadi rekurensi lokal, dengan metastasis secara hematogen dan limfatik. ${ }^{5}$

Saat ini penatalaksanaan RMS orbita tidak hanya dengan penatalaksanaan bedah saja, dengan perkembangan radioterapi dan khemoterapi dapat 
meningkatkan survival rate penderita RMS. ${ }^{6}$ Dibutuhkan kolaborasi antara Konsultan Onkologi Mata dengan Bedah Saraf serta Konsultan Pediatrik Onkologi. ${ }^{4}$

\section{KASUS}

Seorang pasien laki-laki umur 12 tahun, datang ke Rumah Sakit Dr M Djamil Padang dengan keluhan utama mata kanan tampak menonjol sejak satu bulan yang lalu dan tanpa disadari penglihatan mata kanan tidak bisa melihat, disertai riwayat mata merah dan tidak bersekret. Pada pasien ini terdapat riwayat trauma, yaitu pelipis kanan pasien terkena tendangan sejak 2 bulan yang lalu dan terasa bengkak. Pasien sering mengeluh sakit kepala disertai mual dan muntah. Riwayat mata merah sebelumnya tidak ada. Penglihatan kedua mata sebelumnya baik, riwayat memakai kaca mata tidak ada. Riwayat penyakit sistemik disangkal.Riwayat terdapat benjolan dibagian tubuh lain disangkal.

Status oftalmologi mata kanan ditemukan visus 1/300, pada palpebra terdapat edema dan diskolorisasi, konyungtiva tampak hiperemis dan khemosis di bagian inferior. Pada pemeriksaan pupil ditemukan Relative Afferent Pupillary Defect (RAPD) positif. Pemeriksaan funduskopi ditemukan edema papil. Pemeriksaan gerak bola mata terdapat keterbatasan gerak dengan posisi protusio.

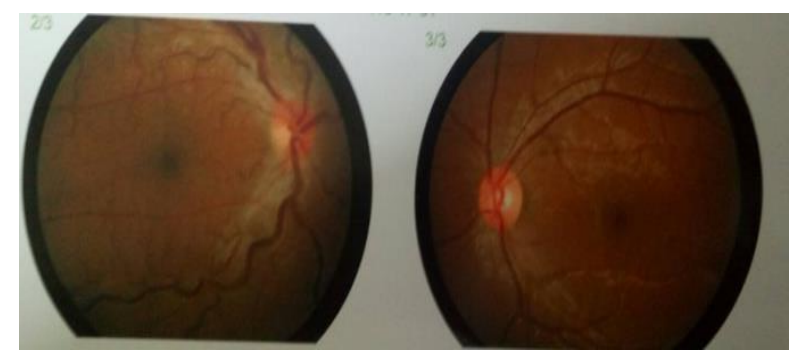

Gambar 1. Gambaran edema papil pada mata kanan.

Hasil pemeriksaan MRI menunjukkan kesan tampak massa padat ekstra aksial, pada Os sphenoid kanan yang mendesak dinding posterolateral orbita kanan, menyempitkan intrakonal sehingga menyebabkan protusio okuli kanan dan menekan otototot ekstra okular dan nervus optikus.

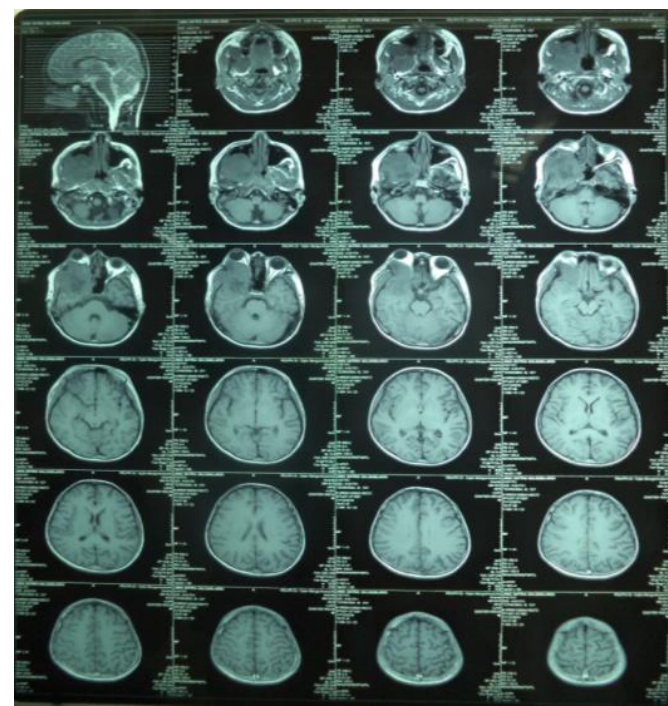

Gambar 2. Hasil pemeriksaan MRI

Pasien ini telah dilakukan tindakan craniotomy dan langsung dilakukan biopsi. Hasil biopsi menunjukkan suatu embryonal rhabdomyosarcoma pada retroorbita. Pada pasien ini terdapat rekurensi tumor setelah 3 bulan pengangkatan tumor. Pada status ophthalmologi mata kanan visus 0 , pelpebra edema(+), diskolorisasi (+). Pada konyungtiva terdapat khemosis $360^{\circ}$, pada kornea terdapat keratopathy dankeratits eksposure (+). Posisi bola mata protusio.

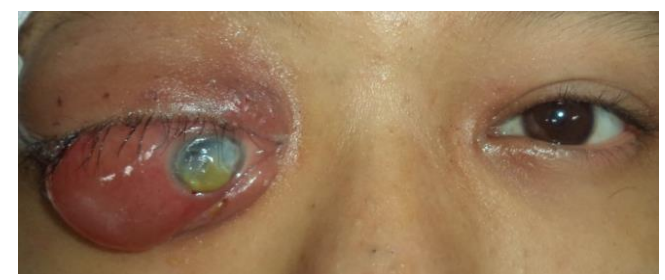

Gambar 3. Diskolosrisasi dan edema pada palpebra , kemosis pada konyungtiva dan keratopathy pada kornea.

\section{PEMBAHASAN}

Dilaporkan kasus Rhabdomyosarcoma (RMS) orbita pada pasien anak laki-laki usia 12 tahun. Anamnesis didapatkan mata kanan tampak menonjol sejak satu bulan yang lalu disertai penurunan penglihatan. Terdapat riwayat trauma pada pelipis kanan sejak 2 bulan yang lalu dan kemudian terasa bengkak dan terdapat riwayat sakit kepala disertai mual dan muntah. Pada status oftalmologi mata kanan ditemukan visus $1 / 300$, pada palpebra terdapat edema 
dan diskolorisasi, konyungtiva tampak hiperemis dan khemosis di bagian inferior. Pada pemeriksaan pupil ditemukan RAPD positif dan pemeriksaan funduskopi ditemukan edema papil. Pemeriksaan gerak bola mata terdapat keterbatasan gerak dengan posisi protusio. Pada awal pemeriksaan ditegakkan diagnosa dengan Protusio bulbi Oculi Dextra (OD) et causa suspek tumor retroorbita, edema papil OD dan parese Nervus III,IV, VI OD dengan diagnosis banding Rhabdo myosarcoma retro obita, limfoma orbita, infiltrasi sel leukemia ke orbita, tumor metastasis ke orbita dan selulitis orbita. Pada pasien ini Rhabdomyosarcoma retroorbita ditegakkan setelah dilakukan craniotomy dan berdasarkan pemeriksaan patologi anatomi post operatif.

Pasien ini didiagnosis Rhabdomyosarcoma retroorbita Oculo Dextra pada usia 12 tahun. RMS orbita terjadi pada dekade pertama sampai kedua kehidupan, dengan rata-rata usia 8 tahun dan berkisar antara umur 2 bulan sampai 7 tahun, dan 90\% dari anak-anak dengan RMS muncul pada usia sebelum 16 tahun. ${ }^{7}$ RMS orbita lebih sering terjadi pada anak laki-laki dibandingkan dengan anak perempuan. Perbandingan berdasarkan jenis kelamin, dengan ratio laki-laki dibandingkan perempuan 3:2. Tidak ada kecenderungan penyakit ini diturunkan secara herediter, meskipun beberapa kasus keganasan dapat juga ditemukan dalam satu keluarga. ${ }^{8}$

Anamnesis didapatkan riwayat trauma pada pelipis kanan yang terjadi 2 bulan sebelum timbulnya gejala klinis. Adanya riwayat trauma pada daerah periokular sering dihubungkan dengan gejala klinis yang muncul pada tumor ini dan sering membuat keterlambatan dalam menegakkan diagnosis RMS. Riwayat trauma ini juga ditemukan pada laporan kasus oleh Bagdonaite et al yang melaporkan kasus RMS orbita pada usia dewasa ( 52 tahun) dengan adanya riwayat trauma tumpul pada daerah periokular. Pada kasus yang dilaporkan oleh Bagdonaite ini, ditemukan adanya memar pada daerah periorbita dan 1 minggu kemudian muncul gejala bengkak pada daerah periorbita, proptosis yang diikuti oleh khemosis konyungtiva. Sampai saat ini adanya hubungan riwayat trauma dengan terjadinya RMS masih belum dapat dijelaskan. ${ }^{4}$
Gejala klinis klasik RMS orbita muncul dengan massa yang berkembang cepat dengan perubahan pada jaringan lunak yang mirip dengan proses terjadinya inflamasi dan pada anak-anak muncul dengan gejala proptosis unilateral atau adanya edema periorbita. $^{9}$ Proptosis dapat muncul secara tiba-tiba dan berkembang cepat dalam beberapa hari sampai beberapa minggu. ${ }^{10}$

Pada pasien ini munculnya proptosis lebih kurang satu bulan disertai dengan gejala yang mirip dengan gejala inflamasi, dimana pada pasien ini ditemukan edema palpebra yang disertai diskolorisasi, konyungtiva hiperemis dengan terdapatnya khemosis di bagian inferior. Diskolorisai dan warna kemerahan pada pada palpebra yang terjadi pada RMS orbita tidak disertai dengan local heat atau demam seperti yang terjadi pada selulitis. ${ }^{11}$ Diskolorisasi pada palpebra diduga terjadi akibat dilatasi vena episklera yang terjadi pada $42 \%$ kasus RMS Orbita. ${ }^{14}$ Adanya proptosis pada pasien ini ditunjang dengan pemeriksaan Hertel Exoptalmolmeter. Pada pasien ini juga ditemukan gangguan gerak bola mata dan terjadi inferior displacement dari bola mata. Displacement bola mata pada RMS orbita terjadi pada $80 \%$ kasus , biasanya terjadinya inferior displacement karena 2/3 dari RMS orbita ini berlokasi pada daerah superonasal. ${ }^{10}$

Gejala klinis dari RMS tergantung dari lokasi tumor ,jika tumor berlokasi di anterior di konyungtiva maupun palpebra dapat menyebabkan edema palpebra, eritema dan khemosis, dan pada beberapa kasus menimbulkan gejala yang menyerupai gejala yang disebabkan oleh infeksi atau inflamasi pada segmen anterior. ${ }^{3}$ Pemeriksaan slit lamp pada konyungtiva terdapat hiperemis konyungtiva, khemosis, keratitis eksposure. Ada tanda inflamasi pada RMS orbita sering diragukan dengan selulitis orbita. Pada pemeriksaan awal terdapat penurunan visus, RAPD (+) pada mata kanan, disertai dengan ditemukannya edema papil pada pemeriksaan funduskopi, hal ini diduga terjadi akibat penekanan Nervus optikus oleh massa tumor di daerah retroorbita. Selain itu terdapat juga gangguan gerak bola mata yang kemungkinan dapat disebabkan oleh penekanan Nervus III,IV, VI oleh massa tumor. 
Gangguan gerak bola mata atau opthalmoplegi terjadi pada $42 \%$ kasus RMS orbita. $^{9}$

RMS orbita dapat mengenai orbita secara keseluruhan, lokasi yang paling sering pada daerah retrobulbar, di daerah superior dan inferior. Lokasi massa tumor pada daerah retro bulbar 50\%, $25 \%$ kasus dengan massa di bagian superior orbita , $12 \%$ di bagian inferior orbita, $6 \%$ di daerah nasal dan $6 \%$ di temporal. Nicula et al melaporkan laporan kasus pasien wanita dengan usia 14 tahun dengan onset terjadinya gejala 3 bulan dan terdapatnya massa tumor yang dapat diraba pada bagian superior. ${ }^{10}$ Pemeriksaan MRI pada pasien ini ditemukan lokasi tumor pada daerah retroorbita dengan perluasan ke ruang masticator dan ruang parapharyngeal kanan serta fossa temporal kanan dan mendestruksi sebagian os temporal kanan, sehingga pada pasien ini ditemukan adanya massa yang teraba pada daerah temporal. Pada pemeriksaan awal tidak ditemukan adanya massa yang teraba di daerah orbita namun 3 bulan setelah pemeriksaan ditemukan adanya massa di orbita bagian superior. Hal ini menunjukkan pada pasien ini terjadi perkembangan tumor yang progresif dan sangat cepat.

Pasien ini telah dilakukan pemeriksaan diagnostik MRI dengan kesan massa padat ekstra aksial,sentrasi di sphenoid wing kanan, mendesak dinding posterolateral orbita kanan, menyempitkan intrakonal menyebabkan proptosis okuli kanan dan menghimpit muskulus ekstra okular dan nervus optikus kanan dengan perluasan ke masticator space dan parapharyngeal space kanan serta fossa temporal kanan, mendestruksi sebagian os temporal kanan, sphenoid wing kanan dan dinding medial sinus sphenoid kanan dan dinding medial sinus sphenoid kanan, sugestif maligna. Pemeriksaan MRI dan CT Scan sangat penting untuk menentukan lokasi tumor dan perluasan tumor, evaluasi preoperatif, staging dan follow up pada RMS orbita. CT Scan Orbita penting untuk deteksi adanya keterlibatan tulang, sedangkan MRI penting untuk menilai resolusi spasial, jaringan lunak, dan penyebaran ke intrakranial. Pemeriksaan CT-scan dan MRI juga dapat digunakan untuk follow up post terapi. Pemeriksaan MRI dapat memperlihatkan adanya residu tumor atau terjadinya rekurensi. $^{10}$
Pasien ini telah dilakukan tindakan craniotomy dan langsung dilakukan biopsi. Hasil biopsi menunjukkan suatu embryonal rhabdomyosarcoma pada retroorbita. Dahulu para ahli menduga RMS orbita berasal dari otot-otot ekstra okular, namun saat ini diyakini bahwa RMS orbita berkembang dari sel-sel mesenkim undifferentiated yang mempunyai kemampuan berdifferensiasi menjadi otot lurik. Data epidemiologi tahun 2013 menunjukkan dari 34 kasus rhabdomyosarcoma tidak terdapat bukti adanya neoplasma yang berasal dari otot-otot ekstraokular. ${ }^{2}$ Berdasarkan pemeriksaan histopatologi terdapat 4 tipe RMS yakni:

1. Embryonal

Lokasi sering pada kuadran superonasal orbita, $57 \%$ dari semua tipe RMS orbita. Merupakan tipe yang paling sering ditemukan. Terdiri dari fasikulus-fasikulus jaringan ikat longgar, sel-sel tumor yang pleomorfik yang mengalami elongasi, dengan nukleus hiperkromatis dikelilingi oleh sitoplasma eosinofilik. Sel-sel tumor berdifferensiasi di sepanjang rhabomyoblastic lines sehingga membentuk sel-sel spindle yang mengalami elongasi. Tipe ini mempunyai survival rate yang baik $(94 \%){ }^{10}$

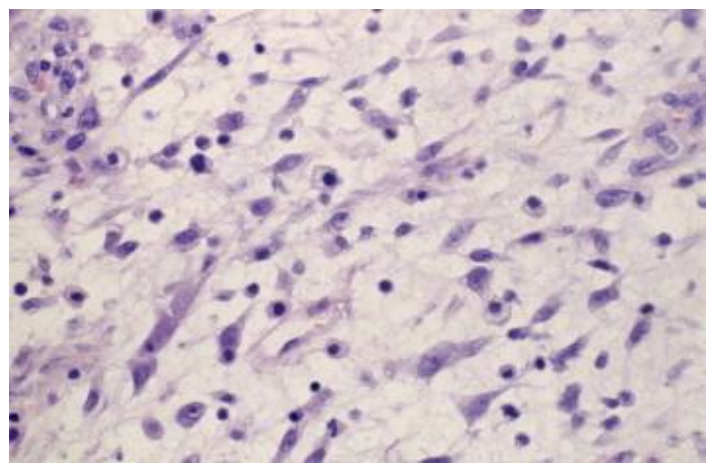

Gambar 4. Embryonal orbital RMS. Terdiri dari sel-sel spindle yang bulat dan mengalami elongasi dengan gambaran otot lurik pada berbagai stadium embriogenesis. Sitoplasma eosinofilik dan nukleolus yang hiperkromatik. ${ }^{10}$

\section{Alveolar}

Lokasi yang paling sering pada kuadran inferior orbita. Kira-kira $19 \%$ dari RMS orbita. Terdiri dari jaringan fibrovaskular dikelilingi oleh rhabdomyoblast yang terdapat di sepanjang jaringan ikat atau terdapat mengambang bebas pada ruang alveolar. Tipe ini 
merupakan tipe yang paling ganas dengan 10-year survival rate nya $10 \% .^{10}$

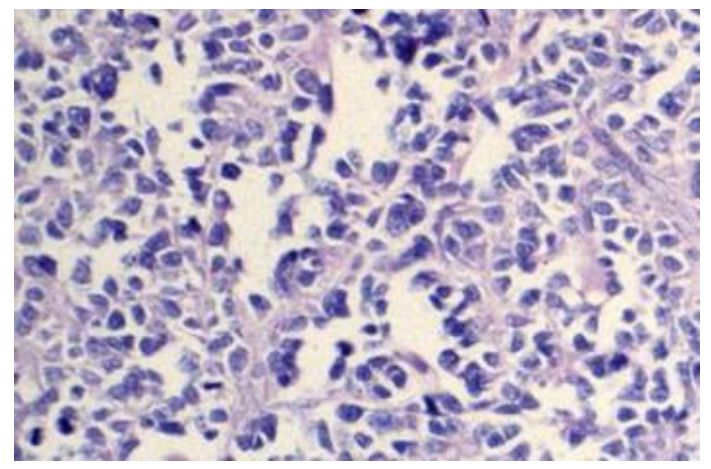

Gambar 5. Alveolar orbital RMS terdiri dari sel-sel yang besar, dengan sel-sel yang besar dengan sitoplasma eosinofilik, sel-sel berbentuk bulat dan poligonal, nukleolus vesikular. ${ }^{10}$

\section{Pleomorphic}

Merupakan bentuk yang paling jarang ditemukan dan tipe yang paling berdifferensiasi. Terjadi pada 6\% dari kasus RMS orbita. Terdiri dari sel-sel berbentuk seperti tali atau bulat. Mempunyai prognosis yang baik dengan survival rate $97 \%$. ${ }^{10}$

\section{Botryoid}

Tipe Botryoid merupakan varian dari embryonal RMS yang jarang ditemukan. Gambaran histopatologis berupa kelompok sel-sel yang berbentuk anggur, tidak ditemukan pada orbita sebagai tumor primer, tetapi merupakan invasi sekunder RMS pada sinus paranasal dan konyungtiva. $^{10}$

Saat ini sudah dikembangkan pemeriksaan Immunohistokimia untuk diagnostik. Tumor Marker yang ditemukan pada RMS diantaranya:

1. Antibodi againts Desmin

Merupakan tumor marker yang paling sering ditemukan (90\%) dan tertap memberikan hasil positif bahkan pada poorly differentiated rhabdomyoblast. ${ }^{6.7}$

2. Muscle-specific actin, myoD1

3. Tumor marker ini mempunyai ekspresi yang tinggi pada sel-sel primitif dan sensitifitasnya minimal pada tipe sel yang berdifferensiasi. Ditemukan pada $71-91 \%$ pada RMS. ${ }^{6,7}$

4. Myoglobin

\section{Myogenin}

Myogenin lebih sering ditemukan pada tipe alveolar dari pada tipe embryonal. ${ }^{6,7}$

6. Vimentin

Tumor marker ini selalu positif pada RMS tetapi, marker ini tidak spesifik untuk RMS karena dapat juga ditemukan pada tumor lain yang berasal dari differensiasi otot lurik. ${ }^{6,7}$

7. Caveolin-3

Merupakan tumor marker baru yang sensitivitas dan spesifisitasnya tinggi pada RMS yang berdifferensiasi dan marker ini dapat membantu mendeteksi sisa tumor setelah dilakukan kemoterapi. ${ }^{7}$

Terapi awal RMS orbita dengan pengangkatan massa tumor semaksimal mungkin dengan tetap mempertahankan struktur yang vital. Pasien ini dilakukan craniotomy yang dilakukan oleh bagian Bedah Syaraf. RMS orbita menunjukkan kecenderungan untuk terjadi invasi lokal, rekurensi lokal dan penyebaran secara hematogen dan limfatik. Terapi pembedahan pada RMS orbita dengan tetap menyisakan periosteum dimana periosteum sebagai barier terhadap penyebaran tumor secara local. Metastasis RMS dapat terjadi hematogen ke paru-paru dan tulang sehingga memerlukan konsultasi dengan Konsultan Pediatrik Onkologi. ${ }^{11}$

Pasien ini setelah dilakukan pengangkatan massa tumor retroorbita dan direncanakan untuk dilakukan kemoterapi dan radioterapi. Saat ini sejak ditemukannya kemoterapi dan radioterapi, manajemen utama dari RMS adalah kombinasi kemoterapi,radioterapi dan pembedahan. Beberapa klinisi di pusat terapi RMS, melakukan terapi pembedahan hanya dengan biopsi eksisi saja, sedangkan beberapa pusat terapi lainnya dengan melakukan pengangkatan tumor secara debulking. ${ }^{3}$ Manajemen standar RMS orbita sebelumnya adalah eksenterasi, namun dengan terapi ini prognosis pasien apalagi pada anak-anak cukup buruk sehingga pada awal tahun 1970, North American Intergroup RMS study Group and European Cooperative Groups memperkenalkan kombinasi terapi dengan kemoterapi 
dan radioterapi , dengan kombinasi terapi ini survival rate penderita RMS meningkat menjadi $90 \%{ }^{12}$

Kemoterapi dan radioterapi dapat diberikan setelah eksisi lokal atau biopsi. Kemoterapi diberikan biasanya 2-3 siklus sebelum diberikan terapi inisiasi radioterapi. ${ }^{12}$ Regimen dasar kemoterapi terdiri dari: ${ }^{5}$

1. Vincristine $(\mathrm{V})$

2. Actinomycin $\mathrm{D}(\mathrm{A})$

3. Cyclophosphamide (C)

Pemberian regimen ini 3 years survival rate pasien RMS dengan metastasis dapat mencapai $55 \% .{ }^{12}$ Setelah dilakukan biopsi, seharusnya dilakukan staging berdasarkan sistem klassifikasi menurut Intergroup Rhabdomyosarcoma Study (IRS) post surgical staging system :

- Grup I: Tumor terlokalisir, dan telah dilakukan reseksi komplit (Biopsi Eksisi)

- Grup II: Terdapat sisa tumor secara mikroskopis setelah dilakukan biopsi.

- Grup III: Terdapat sisa tumor yang besar setelah dilakukan biopsi

- Grup IV: ditemukan adanya metastasis. ${ }^{4}$

Berdasarkan staging ini dapat diputuskan rencana terapi selanjutnya. Berdasarkan IRS post surgical staging system, manajemen dari RMS orbita yaitu:

- Grup I: hanya dengan kemoterapi saja, terdiri dari Vincristine dan Actinomycin (VA) tanpa radioterapi atau dapat juga diberikan radioterapi.

- Grup II: Kombinasi kemoterapi Vincristine , Actinomycin, dan Cyclophosphamide

(VAC )dengan radioterapi 36 Gy

- Grup III: Kombinasi kemoterapi VAC dengan radioterapi 45 Gy

- Grup IV: Kombinasi kemoterapi Intensif dengan radioterapi. $^{12}$

Radioterapi efektif untuk mencapai kontrol lokal tumor pada pasien dengan adanya residual tumor setelah dilakukan biopsi, reseksi tumor, atau kemoterapi. Dosis radioterapi tergantung luasnya tumor setelah dilakukan reseksi. Pasien dengan reseksi komplit (grup I) pada tipe embryonal dapat berhasil tanpa radioterapi, tetapi pada tipe alveolar radioterapi sangat bermamfaat. $^{12}$

Prognosis pasien ini berdasarkan histopatologis mempunyai prognosis yang baik, meskipun pada saat post operatif gejala protusio semakin bertambah, terdapatnya penurunan visus, khemosis konyungtiva $360^{\circ}$ dan diskolorisai palpebra yang semakin nyata. Selain berdasarkan histopatologis, prognosis juga tergantung pada lokasi anatomi tumor, morfologi dan usia pasien. $^{5}$

Pada tahun 1995 International Classification for Childhood Rhabdomyosarcoma memperkenalkan klassifikasi RMS berdasarkan prognostic categories $:^{13}$

I. Superior prognosis
a. Botyroid RMS
b. Spindle cell RMS

II. Intermediate prognosis

a. Embryonal RMS

III. Poor prognosis:
a. alveolar RMS
b. tipe anaplastik difus

IV. Subtipe dengan prognosis yang tidak dapat dievaluasi

Kebanyakan kasus dari RMS orbita mempunyai prognosis dengan 10-year survival rate $77 \%$ pada kasus disertai dengan metastasis dan $87 \%$ pada kasus non-metastasis. Tipe alveolar mempunyai prognosis paling buruk dan mempunyai survival rate paling rendah, sehingga 5 year survival rate pada anak-anak dengan rhabdomyosarcoma alveolar adalah $74 \% .5$ year survival rate pada pasien dengan tipe embryonal rhabdomyosarcoma adalah $67 \%{ }^{3}$

Progresifitas dari gejala klinis pada pasien ini diduga disebabkan karena masih terdapatnya residual tumor pada orbita sehingga direkomendasikan pemeriksaan CT scan orbita atau MRI post operatif untuk follow up dan untuk penatalaksanaan dianjurkan melakukan staging sehingga dapat menentukan manajemen berdasarkan klassifikasi IRS post surgical staging system. Setelah dilakukan terapi , dibutuhkan pemeriksaan secara komprehensif serta pemeriksaan CT-Scan atau MRI, dan follow-up dapat dilakukan setiap 3-4 bulan pada tahun pertama, setiap 4-6 bulan pada beberapa tahun berikutnya. ${ }^{6}$ 


\section{SIMPULAN}

Pada psien ini ditegakkan diagnosis Rhabdomyosarcoma orbita berdasarkan anamnesis onset terjadinya cepat dan progresif, terdapat riwayat trauma yang secara teori tidak terdapat hubungan patofisiologi. Pemeriksaan diagnostik pada pasien ini diantaranya dilakukan pemeriksaan CT-Scan orbita untuk menentukan lokasi tumor dan MRI untuk menentukan perluasan dan adanya keterlibatan tulang. Pada pemeriksaan patologi anatomi dengan hasil terdapatnya RMS orbita tipe embryonal. Penatalaksanaan pasien ini terdiri dari bedah yang dilakukan oleh ahli bedah saraf dan kemoterapi.

\section{SARAN}

Rekomendasi untuk manajemen post operatif pada pasien ini adalah kombinasi radioterapi dan kemoterapi serta follow up pemeriksaan CT Scan Orbita atau MRI untuk melihat adanya residual tumor post operatif.

\section{UCAPAN TERIMA KASIH}

Terimakasih kepada subbagian pediatrik oftalmologi IImu Kesehatan Mata Fakultas Kedokteran Unand, Bagian IImu Kesehatan Anak dan Bedah Saraf yang telah memberikan kontribusi dalam kesempurnaan laporan kasus ini.

\section{DAFTAR KEPUSTAKAAN}

1. Misra S, Patill K, Misra N, Patill K. Advanced case of rhabdomyosarcoma of orbit mimicking orbital cellulitis. Journal of Clinical and Experimental Ophthalmology. 2016;7(2):1-3.

2. Mauatova TT. Epidemiology of ocular tumors in children and adults. Edisi ke-1. Nepal: JaypeeHighlights;2013.hlm.68-74.

3. Nagarkar R, Roy S, Akheel M. Rhabdomysarcoma of orbit: a rare case report and review. IJJS Case Report and review. 2014; 1 (5): 6-10.

4. Bagdonaite L, Jeeva I, Chang YP. Case report; multidisciplinary management of adult orbital rhabdomyosarcoma. Orbit Informa Health Care. 2012;1:1-3.

5. Seregard S. Management of alveolar rhabdomyosarcoma of the orbit. opthalmic pathology and oncology service. Acta Opthalmol Scand. 2012;80:660-4.

6. Shields LC, Shields JA. Orbital myogenic tumors. eyelid, conjunctival, and orbital tumors. Edisi ke-2. Philadelphia: Wolters Kluwer; 2008.hlm.600-13.

7. Skuta GL, Cantor LB, Cioffi AG. Orbital neoplasm and malformations.orbit, eyelid and lacrimal system. San Francisco: American Academy of Ophthalmology; 2014.hlm.76-8.

8. Skuta GL, Cantor LB, Cioffi AG. Orbit. opthalmic pathology and intraocular tumors. $4^{\text {th }}$ Section. San Francisco: American Academy Of Opthalmology; 2014.hlm.242-4.

9. Jurdy L, Merks HM, Pieters BR. Orbital Rhabdo myosarcomas: a review. Saudi Journal of Ophthalmology. Elsevier. 2013;27:167-75.

10. Nicula C, Nicula D, Blidaru M. Case report; orbital rhabdomyosarcoma with a good life prognosis after surgical treatment in a 14 year old patient. Central European Journal of Medicine. Versita. 2014: 10 (3):384-9.

11. Moon S, Kwon SW, Lee HJ. A case of alveolar rhabdomyosarcoma of the ethmoid sinus invading the orbit in an adult. Korean Journal of Ophthalmology. Incheon. 2015;20(2):70-5.

12. Reddy AV, More N, Murtyhy R. Management of opthalmic tumors: role of chemotherapy and radiation therapy. Surgical Atlas of Orbital Disease. Nepal:Jaypee; 2012.hlm.352-3.

13. Hadjistilianou D, Karcioglu A. Malignant pediatric tumors. orbital tumors. New Orleans: Springer; 2015; 304-7. 